\title{
Macromolecular Composition and Nuclear Division During Spore Germination in Aspergillus nidulans
}

\author{
By B. W. BAINBRIDGE \\ Department of Microbiology, Queen Elizabeth College, \\ Campden Hill Road, London W. 8
}

(Accepted for publication Io April 197I)

SUMMARY

Germ-tube emergence in Aspergillus nidulans exhibits partial synchrony. Germ tubes were first detected at $210 \mathrm{~min}$. after inoculation of spores into a liquid medium. Almost all spores produced germ tubes within 360 min., $49.5 \%$ of them doing so between 240 and $300 \mathrm{~min}$. Increase in dry weight was first detected at I $20 \mathrm{~min}$. and various constituents at the following times: RNA (30 min.), Kjeldahl nitrogen (30 min.), protein ( $150 \mathrm{~min}$.) and DNA (180 min.). Pauses in the increase of DNA, RNA and protein were observed. The DNA content per nucleus during the first replication cycle reached twice that of the resting spore, but at later stages of germination values only Io \% higher were observed. Spores containing 2,4 and 8 nuclei were first detected at 270,390 and 480 min. respectively.

\section{INTRODUCTION}

The spores of Aspergillus nidulans (Eidam) Winter are favourable material for spore germination studies (Shepherd, I957; Kessel \& Rosenberger, 1968). The spores (conidiospores or conidia) are uninucleate and can be obtained in large numbers. In addition, studies have been made of nuclear division in $A$. nidulans spores (Weijer \& Weisberg, 1966; Rosenberger \& Kessel, 1967, 1968; Robinow \& Caten, 1969). The present work was undertaken to study nuclear division and macromolecular synthesis during spore germination.

\section{METHODS}

Organisms. Strain BWB 50 bi I ; w3 was used throughout this work. The strain, which has white spores and requires biotin, was originally obtained from Glasgow University.

Preparation of spore suspensions. Thirty ml.volumes of complete medium agar(MacKintosh \& Pritchard, 1963) in $250 \mathrm{ml}$. conical flasks were inoculated with a spore suspension and incubated at $37^{\circ}$ for 7 days. The spores were harvested by adding $20 \mathrm{ml}$. of $0.1 \%$ (v/v) Tween 80 together with sterile glass beads or marbles. The flasks were agitated and the spore suspensions removed under aseptic conditions and pooled. Spore chains were broken with a Rotamixer (Hook \& Tucker Ltd) and hyphal fragments removed by filtration through six layers of sterile muslin. The spores were washed twice and suspended in sterile distilled water. Spore counts were made with a Fuchs-Rosenthal haemocytometer slide, at least 300 spores being counted. Spores thus prepared had a viability of 95 to $99 \%$ after storage at $4^{\circ}$ for several days, although the experiments reported here were carried out within $24 \mathrm{~h}$.

Cultural conditions and media. Spores were added to $400 \mathrm{ml}$. of liquid DAN medium containing $50 \mu \mathrm{g}$. $/ 1$. biotin (Trinci, 1969) in a 21 . conical flask to give a concentration of 
$2 \times 10^{7}$ spores per ml. Higher spore concentrations resulted in auto-inhibition of germination. Flasks were incubated at $37^{\circ}$ on a Gallenkamp orbital shaker at $200 \mathrm{rev} . / \mathrm{min}$. Unless otherwise stated, all times indicated are minutes after inoculation of spores.

Assessment of germ-tube emergence. One ml. samples were added to $0 . \mathrm{I} \mathrm{ml}$. Rose Bengal solution (Lingappa \& Lingappa, 1965) which fixed and stained the spores. In each sample at least 200 spores were examined, and germ-tube emergence was recorded if the germ tube was equal to half the diameter of the spore (Manners, 1966). Some clumping occurred and separation was achieved by agitation of the suspensions with a finely drawn Pasteur pipette. Estimates of germ-tube emergence from replicate flasks gave standard deviations of 2 to $5 \%$ so that a single sample was usually adequate. The standard deviation was greater at lower levels of spore germination and 400 to 500 spores were counted.

Chemical analyses. Samples were withdrawn, frozen quickly in an ethanol/dry ice mixture and stored at $-20^{\circ}$.

Protein. Samples were acidified with ION-perchloric acid (final concentration $0.2 \mathrm{~N}$ ) and kept at room temperature for $30 \mathrm{~min}$. The supernatant was discarded and $2 \mathrm{ml}$. of distilled water and I g. of no. 2 Ballotini beads were added. This mixture was treated with a microprobe on a $100 \mathrm{~W}$ MSE Ultrasonicator for $5 \mathrm{~min}$. The tube was immersed in crushed ice during this process. This treatment resulted in 80 to $90 \%$ disruption of conidia. Sodium hydroxide was added (final concentration IN) and the tube was left overnight. The supernatant was assayed for protein (Lowry, Rosebrough, Farr \& Randall, I95I) with crystalline bovine serum albumin as a standard.

Kjeldahl nitrogen was assayed by the micro-analytical method of Lang (1958). Intact spore samples were extracted with cold $0 \cdot 2 \mathrm{~N}$-perchloric acid as above and assayed with Nessler's reagent after acid digestion.

$R N A$ was assayed by the oricinol method (Schneider, 1957). Intact spore samples were extracted with $0.2 \mathrm{~N}$ perchloric at $4^{\circ}$ and samples were disrupted as above. Ribose was extracted from the disrupted conidia by treatment with $0.5 \mathrm{~N}$-perchloric acid for $30 \mathrm{~min}$. at $70^{\circ}$. Two extractions were made and the extracts pooled. D-Ribose was used as a standard and the RNA present was calculated from the 'apparent' ribose assuming equimolar amounts of nucleotides in RNA.

$D N A$ was assayed by the diphenylamine method of Burton (I956) as modified by Giles \& Myers (1965). Deoxyribose was extracted by the method used for the estimation of RNA as above. 2-Deoxy-D-ribose was used as a standard and DNA was calculated from the 'apparent' deoxyribose assuming G-C content of $50 \%$ (Pontecorvo, I967).

Dry-weight determinations. Spore samples were washed twice with distilled water, collected in tared centrifuge tubes and dried to constant weight at $105^{\circ}$. Duplicate or triplicate samples were taken.

Determination of the number of nuclei per spore. Samples were fixed in $4 \%(\mathrm{v} / \mathrm{v})$ aqueous glutaraldehyde for $24 \mathrm{~h}$. and suspended in $0.05 \mathrm{M}$-sodium phosphate buffer $\mathrm{pH} 7 \cdot 2$ to which acridine orange was added, final concentration $50 \mu \mathrm{g} . / \mathrm{ml}$. (Clutterbuck \& Roper, I966). Spores were stained for 10 to $30 \mathrm{~min}$. and spore clumps were separated with a finely drawn Pasteur pipette. The spores were suspended in phosphate buffer and viewed with a Zeiss photomicroscope with an ultraviolet light source (barrier filters 50 and 40, exciter filters I and/or II), the nuclei appearing green and the cytoplasm red. The nuclei present in at least 40 spores were usually counted. Estimates on replicate samples showed standard deviations of less than $5 \%$. A single estimate was made for most experiments but in the early stages of germination at least 200 spores were counted. Dividing nuclei were seen in only $I$ in 50 spores, as was also found by Rosenberger \& Kessel (1967), and were ignored. 


\section{RESULTS}

Germ-tube emergence. Germ-tube emergence was detected at $210 \mathrm{~min}$. and the maximum value of 95 to $98 \%$ spores with germ tubes was reached at $360 \mathrm{~min}$. (Table I) $; 49.5 \%$ of the spores produced germ tubes between 240 and $300 \mathrm{~min}$. The percentage of spores which started to produce germ tubes in $30 \mathrm{~min}$. intervals after inoculation showed a skewed distribution similar to that found by Vary \& Halvorson (1965) for Bacillus spore germination. An analysis of the kinetics of germ-tube emergence using the method of McCormick (1964, I965) will be published elsewhere (B. W. Bainbridge, in preparation).

\section{Table I. Germ-tube emergence, dry weight and changes in macromolecules during spore germination}

All estimates, except for germ-tube emergence, are $\mu \mathrm{g} . / 10^{8}$ spores.

\begin{tabular}{|c|c|c|c|c|c|c|}
\hline $\begin{array}{c}\text { Time } \\
\text { (min.) }\end{array}$ & $\begin{array}{c}\text { Germ-tube } \\
\text { emergence } \\
(\%)\end{array}$ & $\begin{array}{c}\text { Dry } \\
\text { weight }\end{array}$ & RNA & $\begin{array}{c}\text { Kjeldahl } \\
\text { nitrogen } \\
\times 6.25\end{array}$ & Protein & DNA \\
\hline 0 & - & 950 & $82 \cdot 9$ & 150 & 133 & $2 \cdot 16$ \\
\hline 30 & - & - & $86 \cdot 2$ & 200 & - & - \\
\hline 60 & 一 & 903 & $99 \cdot 4$ & 260 & 137.5 & $2 \cdot 16$ \\
\hline 90 & - & - & 108 & 287 & 129 & - \\
\hline 120 & - & I IOI & 106 & 486 & - & $2 \cdot 2$ \\
\hline 150 & - & - & I 88 & 537 & I7I & - \\
\hline 180 & - & 1450 & - & 500 & 270.5 & $3 \cdot 8$ \\
\hline 210 & $5 \cdot 3$ & - & 183 & 675 & - & - \\
\hline 240 & 23.5 & 1740 & 238 & 975 & 316 & $4 \cdot 5$ \\
\hline 270 & 57 & - & 309 & 1150 & - & - \\
\hline 300 & 73 & 2680 & 635 & - & 346 & 4.4 \\
\hline 330 & 88 & - & - & 1040 & 358 & - \\
\hline 360 & 95 & 2710 & 822 & 1700 & - & $4 \cdot 8$ \\
\hline 390 & 96 & - & 1095 & - & 790 & - \\
\hline 420 & 98 & 2480 & 1265 & 1600 & 1000 & 5.8 \\
\hline 450 & - & - & - & - & 1065 & - \\
\hline 480 & - & 5720 & 1490 & 3200 & 1435 & $8 \cdot 13$ \\
\hline 510 & - & - & - & 4300 & 1875 & - \\
\hline 540 & - & 7580 & I 630 & - & 2165 & - \\
\hline
\end{tabular}

Synthesis of macromolecules. Increases in RNA and Kjeldahl nitrogen were detected at $30 \mathrm{~min}$. and dry weight and protein increases at 120 and I $50 \mathrm{~min}$. respectively (Table I). Increase in DNA was detected at $180 \mathrm{~min}$. There appeared to be pauses in the synthesis of macromolecules. Shoulders appeared between 150 to $210 \mathrm{~min}$. for RNA, 240 to $330 \mathrm{~min}$. for protein and 240 to $360 \mathrm{~min}$. for DNA. The estimate of Kjeldahl nitrogen showed two shoulders at $\mathrm{I} 20$ to I 80 and 240 to $330 \mathrm{~min}$. The plateau for DNA content occurred when the DNA content per spore was almost exactly twice that present in the ungerminated spore (Table I). Dry weight, nitrogen content and macromolecular synthesis all had a doubling time of approximately $90 \mathrm{~min}$. (Fig. I).

Numbers of nuclei per spore. Counts of the number of nuclei per spore showed that nuclear division first occurred at $270 \mathrm{~min}$. (Table 2). The mean number of nuclei per spore had a doubling time of $90 \mathrm{~min}$. (Fig. 1). Spores with 2, 4 and 8 nuclei appeared at 270,390 and $480 \mathrm{~min}$. respectively (Table 2). Between $\mathrm{I} 20$ and $240 \mathrm{~h}$. the amount of DNA per nucleus doubled, presumably as a result of DNA replication in most nuclei. The DNA content per nucleus then decreased to a value only slightly greater than that of the ungerminated spore. 


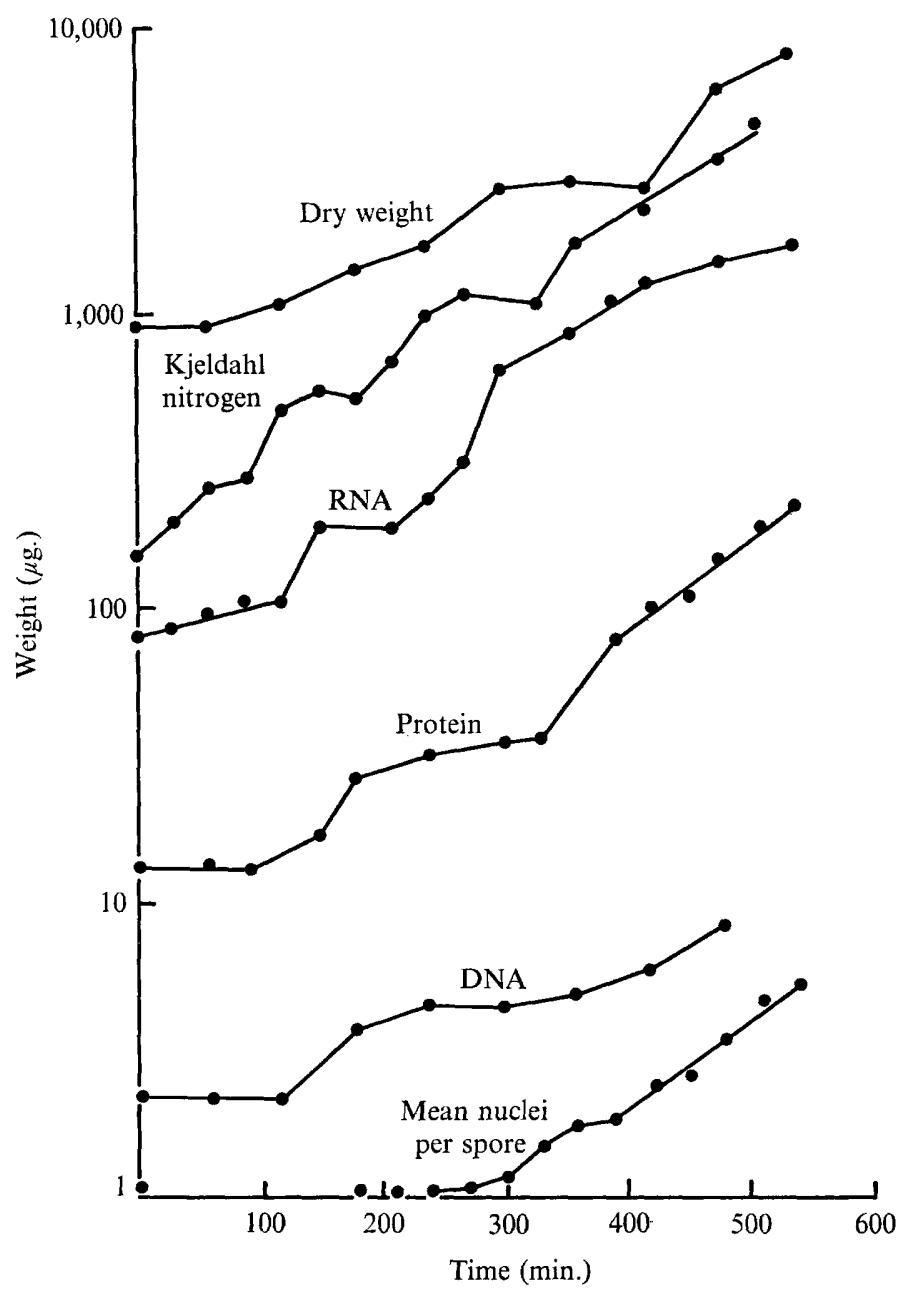

Fig. I. Changes in mean number of nuclei per spore, DNA, protein, RNA, Kjeldahl nitrogen and dry weight during germination. Ordinates show $\mu \mathrm{g}$. $/ 10^{8}$ spores except for protein which is $\mu \mathrm{g}$. $/ 10^{7}$ spores and mean nuclear number which is numerical.

\section{DISCUSSION}

Partial synchrony of spore germination as judged by germ-tube emergence can be achieved in Aspergillus nidulans although lack of synchrony has been reported by Rosenberger \& Kessel (1967). Conditions of incubation and strains used are important as high spore density and certain mutations reduce synchrony of germination (B. W. Bainbridge, unpublished results).

The partial synchrony of germ-tube emergence was also observed in nuclear division as at $360 \mathrm{~min} .70 \%$ of the spores had two nuclei. However, after this synchrony was lost spores containing I, 2, 4 and 8 nuclei were observed at $480 \mathrm{~min}$., as was found by Rosenberger \& Kessel (1967). Partial synchrony of DNA replication was suggested by the occurrence of a pause in DNA increase at a stage when the DNA content per spore had almost exactly doubled, as was found in Aspergillus niger (Yanagita, 1957). An estimate can be made of the 
times of the phases of nuclear replication and division. Eukaryotic nuclei exhibit a resting period after division (GI), a period of DNA synthesis (S), a resting period after DNA synthesis $\left(\mathrm{G}_{2}\right)$ and mitosis during a division cycle. DNA replication was first detected at I 20 to $180 \mathrm{~min}$. and nuclear division occurred at $270 \mathrm{~min}$. This means that the sequence of the phases S-G 2-mitosis must last for a period of 90 to $150 \mathrm{~min}$. The $\mathrm{S}$ period has been estimated at $20 \mathrm{~min}$. (Kessel \& Rosenberger, 1968) whilst nuclear division takes only a few minutes. The phase $\mathrm{G} 2$, by difference, must last therefore for a period of approximately 70 to I $30 \mathrm{~min}$. This conclusion is supported by the DNA content of the nuclei being twice that of the ungerminated spore nucleus. If the period $\mathrm{G}_{2}$ was very short and mitosis therefore occurred almost immediately after the period $\mathrm{S}$, then the amount of DNA per nucleus would be much lower.

Table 2. Germ-tube emergence, nuclei per spore and mean DNA content per nucleus during spore germination

\begin{tabular}{|c|c|c|c|c|c|c|c|c|c|}
\hline \multirow{2}{*}{$\begin{array}{l}\text { Time } \\
\text { (min.) }\end{array}$} & \multirow{2}{*}{$\begin{array}{c}\text { Germ-tube } \\
\text { emergence } \\
(\%)\end{array}$} & \multicolumn{3}{|c|}{$\begin{array}{c}\% \text { Spores with } x \text { nuclei } \\
\text { per spore }\end{array}$} & \multirow[b]{2}{*}{8} & \multirow{2}{*}{$\begin{array}{l}\text { Spores } \\
\text { counted }\end{array}$} & \multirow{2}{*}{$\begin{array}{c}\text { Mean } \\
\text { no. of } \\
\text { nuclei/ } \\
\text { spore }\end{array}$} & \multirow{2}{*}{$\begin{array}{l}\mathrm{DNA} / 10^{8} \\
\text { spores }\end{array}$} & \multirow{2}{*}{$\begin{array}{r}\text { Relative } \\
\text { DNA/ } \\
\text { nucleus }\end{array}$} \\
\hline & & I & 2 & 4 & & & & & \\
\hline 0 & - & 100 & - & - & - & 100 & I & $2 \cdot I 6$ & I \\
\hline 30 & - & - & - & - & - & - & - & - & - \\
\hline 60 & - & - & - & - & - & - & - & $2 \cdot I 6$ & I \\
\hline 90 & - & - & - & - & - & - & - & - & - \\
\hline 120 & - & - & - & 一 & - & - & - & $2 \cdot 2$ & 1.02 \\
\hline 150 & - & - & 一 & - & - & - & - & - & - \\
\hline 180 & - & 100 & - & - & - & IIO & I & $3 \cdot 8$ & $I \cdot 76$ \\
\hline 210 & $5 \cdot 3$ & 100 & - & - & - & 100 & I & - & - \\
\hline 240 & $23 \cdot 5$ & 100 & - & - & - & 106 & I & $4 \cdot 5$ & 2.08 \\
\hline 270 & 57 & $98 \cdot 12$ & $\mathrm{I} \cdot 88$ & - & - & 106 & I.02 & - & - \\
\hline 300 & 73 & $92 \cdot 3$ & $7 \cdot 7$ & 一 & 一 & 104 & $\mathrm{I} \cdot \mathrm{I} 2$ & 4.4 & $\mathrm{I} \cdot 92$ \\
\hline 330 & 88 & $52 \cdot \mathrm{I}$ & $47 \cdot 9$ & - & - & 92 & $I \cdot 46$ & - & - \\
\hline 360 & 95 & $28 \cdot 3$ & $71 \cdot 7$ & - & - & $8 I$ & $1 \cdot 72$ & $4 \cdot 8$ & $1 \cdot 29$ \\
\hline 390 & 96 & $24 \cdot 7$ & $70 \cdot 8$ & 4.5 & - & 89 & $\mathrm{I} \cdot 85$ & - & - \\
\hline 420 & 98 & I 3.6 & $64 \cdot 4$ & 22 & - & 59 & $2 \cdot 37$ & $5 \cdot 8$ & $I \cdot 13$ \\
\hline 450 & - & $4 \cdot I$ & $58 \cdot 9$ & 37 & - & 73 & $2 \cdot 56$ & - & - \\
\hline 480 & - & 0 & 30.5 & $67 \cdot 8$ & $1 \cdot 7$ & 59 & 3.46 & $8 \cdot 13$ & I.09 \\
\hline $510^{\circ}$ & - & $2 \cdot \mathrm{I} 3$ & $\mathrm{I} 2.8$ & $63 \cdot 8$ & $21 \cdot 27$ & 47 & $4 \cdot 67$ & - & - \\
\hline 540 & - & 0 & $8 \cdot 6$ & $57 \cdot \mathrm{I}$ & $34 \cdot 3$ & 35 & $5 \cdot 2$ & - & - \\
\hline
\end{tabular}

However, estimates for the period G 2 of later division cycles differ. At 420 and $480 \mathrm{~min}$. DNA replication in the spores is essentially asynchronous and the DNA per nucleus is approximately $110 \%$ that of nuclei of ungerminated spores. An asynchronous culture of bacteria, in which DNA synthesis is continuous with one replication fork, would be expected to have a value of DNA per nucleus of $1 \cdot 4$ compared to an unreplicated nucleus (Pritchard, Barth \& Collins, I969). DNA synthesis in eukaryotes is, however, discontinuous and the DNA per nucleus will be affected by the ratio of the lengths of the phases $\mathrm{G}$ I and G2. When phase $G_{2}$ is long and phase $G_{I}$ is short, the DNA content per nucleus in a population of spores might be nearly double that in ungerminated spores. A value only slightly greater than that of the resting spore would suggest that phase $G_{I}$ is long and that phase $\mathrm{G}_{2}$ is short. This contrasts with a yeast system in which phase $G_{I}$ is short (Williamson, 1965). Kessel \& Rosenberger (1968) found that the length of phases G I and G 2 in Aspergillus nidulans can be altered by changing growth conditions.

The synthesis of other macromolecules followed the expected pattern, RNA synthesis 
preceding protein synthesis as found by van Etten (1969). However, the pauses in the synthesis of these other macromolecules were unexpected and may be associated with the initial nuclear division or with organizational changes in the spore during germination. A pause was also observed in dry weight increase at the time of germ-tube emergence. Possibly this is due to carbohydrate reserves being used for cell-wall synthesis or to the washing away of the outer layer of the spore wall which is sloughed off the spore at this stage (Border \& Trinci, 1970).

Thanks are due to the excellent technical assistance of Miss Christine Newell and to Drs M. Bazin, D. J. Border, A. J. Clutterbuck, A. P. J. Trinci and R. F. Rosenberger for helpful discussion.

\section{REFERENCES}

Burton, K. (1956). A study of the conditions and mechanism of the diphenylamine reaction for the colorimetric estimation of deoxyribonucleic acid. Biochemical Journal 62, 31 5-323.

Border, D. J. \& TRINCI, A. P. J. (1970). Fine structure of the germination of Aspergillus nidulans conidia. Transactions of the British Mycological Society 54, I43-152.

Clutterbuck, A. J. \& Roper, J. A. (I966). A direct determination of nuclear distribution in heterokaryons of Aspergillus nidulans. Genetical Research, Cambridge 7, I85-194.

van Etten, J. L. (1969). Protein synthesis during fungal spore germination. Phytopathology 59, 1060-1064.

GILES, K. W. \& MYERS, A. (1965). An improved diphenylamine method for the estimation of deoxyribonucleic acid. Nature, London 206, 93.

Kessel, M. \& Rosenberger, R. F. (I968). Regulation and timing of deoxyribonucleic acid synthesis in hyphae of Aspergillus nidulans. Journal of Bacteriology 95, 2275-228I.

LANG, C. A. (1958). Simple microdetermination of Kjeldahl nitrogen in biological materials. Analytical Chemistry 30, 1692-I 694 .

LINGAPPA, B. T. \& LiNGAPPA, Y. (1965). Effects of nutrients on self-inhibition of conidia of Glomerella cingulata. Journal of General Microbiology 41, 67-75.

Lowry, O. H., Rosebrough, N. J., FarR, A. L. \& Randall, R. J. (195I). Protein measurement with the Folin phenol reagent. Journal of Biological Chemistry 192, 265-275.

McCormick, N. G. (1964). The time course of spore germination. Biochemical and Biophysical Research Communications 14, 443-446.

MCCORMiCK, N. G. (I965). Kinetics of spore germination. Journal of Bacteriology 89, I I80-I 185.

MacKintosh, M. E. \& PritchaRd, R. H. (1963). The production and replica plating of micro-colonies of Aspergillus nidulans. Genetical Research, Cambridge 4, 320-322.

Manners, J. G. (1966). Assessment of germination. In The Fungus Spore, pp. I65-I73. Edited by M. F. Madelin. London: Butterworths.

Pontecorvo, G. (1967). DNA of Aspergillus nidulans. Aspergillus Newsletter 8, I0-II.

Pritchard, R. H., Barth, P. T. \& Collins, J. (1969). Control of DNA synthesis in bacteria. Symposia of the Society for General Microbiology 19, 263-297.

Robinow, C. F. \& CATEN, C. E. (1969). Mitosis in Aspergillus nidulans. Journal of Cell Science 5 403-43I.

Rosenberger, R. F. \& Kessel, M. (1967). Synchrony in nuclear replication in individual hyphae of Aspergillus nidulans. Journal of Bacteriology 94, I464-1469.

Rosenberger, R. F. \& KeSSEL, M. (1968). Non-random sister chromatid segregation and nuclear migration in hyphae of Aspergillus nidulans. Journal of Bacteriology 96, 1208-1213.

SCHNEIDER, W. C. (1957). Determination of nucleic acids in tissues by pentose analysis. In Methods in Enzymology, vol. 3, pp. 680-684. Edited by S. P. Colowick \& N. O. Kaplan. New York: Academic Press.

SHEPHERD, C. J. (1957). Changes occurring in the composition of Aspergillus nidulans conidia during germination. Journal of General Microbiology r6, i.

TrINCI, A. P. J. (1969). A kinetic study of the growth of Aspergillus nidulans and other fungi. Journal of General Microbiology 57, 1 1-24.

VARY, J. C. \& Halvorson, H. O. (1965). Kinetics of germination of Bacillus spores. Journal of Bacteriology 89, 1340-1347. 
Weijer, J. \& Weisberg, S. H. (1966). Karyokinesis of the somatic nuclei of Aspergillus nidulans. I. The juvenile chromosome cycle (Feulgen staining). Canadian Journal of Genetics and Cytology 8, 361-374.

Williamson, D. H. (1965). The timing of DNA synthesis in the cell cycle of Saccharomyces cerevisiae. Journal of Cell Biology 25, 517-528.

YANAGITA, T. (1957). Biochemical aspects on the germination of conidiospores of Aspergillus niger. Archiv für Mikrobiologie 26, 329-344. 